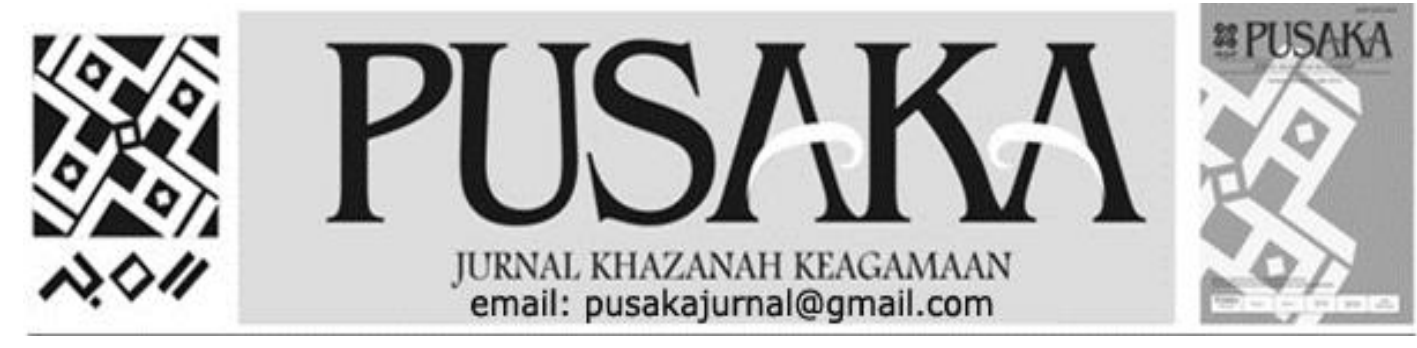

\title{
Penerapan Aspek Yuridis, Sosial dan Ekonomi Pengelolaan Zakat di Kota Palopo untuk Kesejahteraan Masyarakat
}

\author{
Implementation of Juridical, Social and Economic Aspects Of Zakat \\ Management In Palopo City For Community Welfare
}

Muh. Abduh Halid

Sekolah Tinggi Agama Islam (STAI) Darud Dakwah wal-Irsyad (DDI) Jl. Sultan Alauddin 3 No. 8 Makassar

Email: muhabduhhalid@gmail.com

\begin{tabular}{|c|c|}
\hline $\begin{array}{c}\text { Info } \\
\text { Artikel }\end{array}$ & Abstract \\
\hline $\begin{array}{c}\text { Diterima } \\
12 \\
\text { Maret } \\
2018 \\
\\
\text { Revisi I } \\
8 \\
\text { April } \\
2018\end{array}$ & $\begin{array}{l}\text { Penelitian ini bertujuan memberikan pemahaman lebih kongkret tentang pengelolaan zakat } \\
\text { dalam penerapan aspek hukum, aspek sosial dan aspek ekonomi sebagai salah satu } \\
\text { rukun Islam, yang merupakan suatu kekuatan raksasa dalam Islam di bidang ekonomi } \\
\text { dan sosial, di samping sebagai kekuatan spiritual dalam beribadah kepada Allah swt., } \\
\text { yang wajib dilaksanakan oleh umat Islam sebagai wujud pernyataan keimanannya. } \\
\text { Apabila ini dilaksanakan dengan baik, sungguh-sungguh, transparan, dan bertanggung } \\
\text { jawab, akan berdampak positif dalam kehidupan manusia, baik bagi yang menunaikannya } \\
\text { maupun kepada yang menerimanya. Penelitian ini menggunakan metode kualitatif } \\
\text { deskriptif yang ditunjang dengan data dan informasi dalam penelitian lapangan yang } \\
\text { dilakukan di Kota Palopo sebagai sebuah kota yang menjadi obyek penelitian dalam hal } \\
\text { pengelolaan zakat, dengan berusaha mengungkap sejauh mana pengaruh yang } \\
\text { ditimbulkan dalam kehidupan masyarakat dalam penerapan aspek yuridis (hukum) } \\
\text { terhadap lembaga pengelola zakat, aspek sosial dan ekonomi dalam perwujudan } \\
\text { kesejahteraan serta peningkatan kualitas hidup masyarakat dalam pengelolaan zakat } \\
\text { berdasarkan Undang-undang Nomor } 23 \text { Tahun } 2011 \text { tentang Pengelolaan Zakat dan } \\
\text { berbagai peraturan lainnya yang berkaitan dengan pengelolaan zakat di Indonesia. } \\
\text { Dengan pengelolaan zakat yang baik, profesional, transparan dan akuntabel akan } \\
\text { menjadikan zakat lebih berdaya guna dan berhasil guna, dalam mewujudkan kesejahteraan, } \\
\text { terutama bagi kaum duafa yang sangat membutuhkannya, sehingga zakat akan } \\
\text { dirasakan kemanfaatannya sebagai suatu ajaran Islam yang dapat mengangkat harkat } \\
\text { dan martabat manusia di sisi Tuhannya, maupun dalam pandangan manusia. } \\
\text { Kata Kunci : Zakat, Hukum, dan Kesejahteraan }\end{array}$ \\
\hline $\begin{array}{c}\text { Disetujui } \\
1 \\
\text { Mei } \\
2018\end{array}$ & $\begin{array}{l}\text { This study aims to provide a more concrete understanding of the management of zakat in the } \\
\text { application of legal aspects, social aspects and economic aspects as one of the pillars of } \\
\text { Islam, which is a giant force in Islam in the economic and social fields, in addition to being a } \\
\text { spiritual force in worshiping Allah Almighty., which must be carried out by Muslims as a } \\
\text { form of statement of his faith.If this is carried out properly, earnestly, transparently and } \\
\text { responsibly, it will have a positive impact on human life, both for those who fulfill it and those } \\
\text { who receive it. This research uses descriptive qualitative method which is supported by data } \\
\text { and information in field research conducted in the City of Palopo as a city that is the object of } \\
\text { research in terms of zakat management, by trying to reveal the extent of influence caused in } \\
\text { people's lives in the application of juridical (legal) aspects towards zakat management } \\
\text { institutions, social and economic aspects in the realization of welfare and improvement of the } \\
\text { quality of life of the community in the management of zakat based on Law Number } 23 \text { of } 2011 \\
\text { concerning Management of Zakat and various other regulations relating to the management } \\
\text { of zakat in Indonesia. With good, professional, transparent and accountable zakat } \\
\text { management will make zakat more efficient and effective, in realizing prosperity, especially } \\
\text { for the poor who are in dire need of it, so that zakat will be felt as an Islamic teaching that } \\
\text { can elevate human dignity in side of God, as well as in human view. } \\
\text { Keywords: Zakat, Law, and Welfare }\end{array}$ \\
\hline
\end{tabular}




\section{PENDAHULUAN}

Salah satu tujuan Nasional yang hendak diwujudkan dalam Negara Kesatuan Republik Indonesia adalah "Memajukan Kesejahteraan Umum" sebagaimana yang diamanatkan dalam Pembukaan Undang-Undang Dasar 1945. Untuk mewujudkan tujuan Nasional tersebut, bangsa Indonesia senantiasa melaksanakan pembangunan yang bersifat fisik material dan mental spiritual, antara lain melalui pembangunan di bidang agama, mencakup terciptanya suasana kehidupan beragama yang penuh keimanan dan ketakwaan kepada Tuhan Yang Maha Esa, meningkatnya akhlak mulia, terwujudnya kerukunan hidup umat beragama yang dinamis sebagai landasan persatuan dan kesatuan bangsa dan meningkatnya peran serta masyarakat dalam pembangunan nasional. Guna mencapai tujuan tersebut, perlu dilakukan berbagai upaya, antara lain dengan menggali dan mengembangkan serta memanfaatkan potensi yang dimiliki oleh umat Islam.

$$
\text { Islam secara prinsip }
$$

mengajarkan umatnya untuk hidup bahagia dan sejahtera dunia dan akhirat. Hal itu berarti Islam menghendaki umatnya membangun kehidupan yang makmur dan bermoral, jauh dari kesan kemunduran, keterbelakangan dan kemiskinan. Sejak dahulu umat Islam senantiasa mendambakan kehidupannya berada dalam posisi strategis "khairah ummah" umat yang sebaik-baiknya, sempurna dalam segala aspek, baik rohani maupun jasmani, duniawi maupun ukhrawi. Meskipun dalam sejarah, umat Islam, pernah menorehkan tinta emas ketika mengukir kemajuan peradaban dan kemakmuran di abad pertengahan, tetapi kemudian mengalami pasang surut yang ditandai dengan jatuhnya dunia Islam ke jurang kemunduran dan keterbelakangan hidup di bawah tekanan dan kekuasaan kaum imperialis penjajah di berbagai belahan dunia.

Indonesia merupakan salah satu contoh bagi kemunduran dunia Islam, di mana masih banyak umat yang terbelakang dalam pendidikan dan kesejahteraan ekonomi, baik di kota-kota maupun di daerah-daerah terpencil. Kondisi ini tidak terbantahkan lagi, masalahnya adalah langkah apa yang seyogyanya harus dilakukan dan ditempuh untuk mengangkat harkat dan martabat umat Islam yang demikian itu. Memang tidak dapat disangkal bahwa dewasa ini pemerintah telah berupaya meningkatkan kesejahteraan masyarakat melalui berbagai program baik dalam bidang kesehatan, pendidikan maupun dalam perbaikan kesejahteraan melalui pemberian bantuan langsung tunai dan pembagian beras bagi masyarakat miskin, (RASKIN) serta percepatan pembangunan bagi daerah tertinggal (Inpres Desa Tertinggal) dan lain-lain. Namun harus disadari bahwa upaya meningkatkan tarap hidup masyarakat bukanlah tanggung jawab pemerintah saja, melainkan tanggung jawab semua pihak. 
Dalam Islam banyak potensi ekonomi yang seharusnya dikembangkan oleh umat Islam, salah satu di antaranya adalah zakat dalam arti umum meliputi infak dan sedekah. Sebagai salah satu instrumen ekonomi dalam Islam yang harus dikembangkan dan dikelola dengan baik, agar zakat lebih berdaya guna dan berhasil guna dalam mewujudkan kesejahteraan masyarakat dan meningkatkan tarap hidup umat Islam.

Dalam sebuah hadis Rasulullah saw. dari Muaz bin Jabal r.a beliau bersabda:"Beritahukan kepada mereka bahwa Allah swt. telah mewajibkan sedekah atas harta mereka yang diambil dari orang-orang kaya, lalu diberikan lagi kepada orang-orang miskin di kalangan mereka". (Sahih Bukhari, t.th. : 456 ).

Syekh Mahmud Syaltut memberi komentar atas hadis Mu'az di mana pelajaran yang diberikan Nabi saw. itu menunjukkan bahwa dalam pandangan Islam, zakat itu adalah pembiayaan yang diberikan dari sebagian harta suatu kelompok umat Islam yaitu mereka yang kaya kepada umat itu sendiri, yang diwakili oleh kaum fakir/miskin. Penjelasan terhadap hadis tersebut menggambarkan bahwa harta yang diambil dari orang-orang kaya yang selanjutnya diserahkan kepada yang miskin, merupakan suatu pergerakan ekonomi yang harus tumbuh dan berkembang di kalangan masyarakat Islam, sekaligus menumbuhkan sifat-sifat sosial di kalangan masyarakat. Zakat harus menggerakkan roda perekonomian dalam masyarakat dan memajukan kesejahteraan masyarakat/ umat Islam, (Mahmud Syaltut, Al-Islaam, Aqidah wa Syari'ah, 1979 : 169 ). Sebagaimana juga ditegaskan Allah swt. dalam QS. al-Taubah/9 : 60 sebagai berikut;

Terjemahnya :

Sesungguhnya zakat-zakat itu, hanyalah untuk orang-orang fakir, orang-orang miskin, penguruspengurus zakat, para mu'allaf yang dibujuk hatinya, untuk (memerdekakan) budak, orangorang yang berhutang, untuk jalan Allah dan orang-orang yang sedang dalam perjalanan, sebagai sesuatu ketetapan yang diwajibkan Allah; dan Allah Maha Mengetahui lagi Maha Bijaksana (Kementerian Agama, 2015)

Ayat tersebut memberikan penegasan bahwa zakat-zakat yang dikumpulkan dari umat Islam itu harus digunakan dengan sebaikbaiknya dalam pembinaan dan perwujudan kesejahteraan bagi masyarakat miskin, serta untuk pengembangan kegiatan-kegiatan sosial lainnya. Lahirnya Undangundang Nomor 23 Tahun 2011 tentang Pengelolaan Zakat merupakan landasan yuridis yang kuat dalam pengelolaan zakat di Indonesia secara formal, agar dalam pelaksanaannya mendatangkan manfaat yang sebesar-besarnya bagi kesejahteraan masyarakat/umat Islam.

Namun sangat disayangkan
bahwa pengelolaan zakat yang
telah dilaksanakan
lembaga/organisasi pengelola zakat
yang dibentuk berdasarkan
peraturan perundang-undangan yang


berlaku, saat ini masih belum mampu mengangkat harkat dan martabat kaum muslimin. Di kalangan masyarakat masih banyak dijumpai orang-orang Islam yang hidup dalam ke tidak berdayaan, kesulitan ekonomi, kemiskinan, menjadi pengangguran dan sebagainya.

Oleh karena itu Penelitian ini dimaksudkan untuk melihat sejauh mana potensi yang ada dalam pengelolaan zakat ini dapat dikembangkan baik dalam aspek hukumnya (peraturan perundangundangan dan fikih/hukum Islam) yang menjadi landasan pengelolaan zakat oleh lembaga/organisasi pengelola zakat selama ini, serta melihat sejauh mana zakat telah memberikan manfaat sosial dan ekonomi dalam mewujudkan kesejahteraan masyarakat, terutama bagi umat Islam yang masih berada dalam kategori fakir dan miskin, di Kota Palopo sebagai lokus penelitian.

Zakat adalah salah satu rukun Islam yang wajib ditunaikan oleh setiap muslim terutama bagi yang telah memenuhi ketentuan untuk menunaikannya sebagaimana ditegaskan dalam hadis Rasulullah saw. dari Abu Musa al-Asyari dalam riwayat Bukhari, artinya :

"Bersabda Rasulullah saw. setiap orang Muslim wajib bersedekah" mereka bertanya "Hai Nabi Allah bagaimana yang tidak berpunya?. Beliau menjawab, "Bekerjalah untuk mendapat sesuatu untuk dirinya, lalu bersedekah." Mereka bertanya, "kalau tidak punya pekerjaan?" Beliau bersabda, "Tolong orang yang meminta pertolongan", Mereka bertanya, "Bagaimana bila tidak bisa.?" Beliau menjawab, "Kerjakan kebaikan dan tinggalkan kejelekan, hal itu merupakan sedekahnya." (www.noerkhaliazelaik ha.blogspot.com/ 6 Agustus 2018)

Hadis ini memberikan motivasi yang tinggi kepada setiap muslim untuk berusaha dalam hidupnya agar ia mampu memenuhi kebutuhan hidupnya, dan setelah berhasil dalam usahanya maka dianjurkan untuk berzakat atau bersedekah sebagai suatu perintah agama.

Bagaimana konsep zakat dalam Islam? Dalam berbagai kajian kitab fikih, Fukaha di antaranya Abdurrahman al-Jaziri memberikan pengertian zakat secara bahasa, adalah : لنَطْهُوْرُ “ (penyucian dan pertumbuhan). Dan secara istilah syara' menurut al-Jaziri adalah: "Penyerahan (pemindahan) pemilikan tertentu kepada orang yang berhak menerimanya dengan syarat-syarat tertentu pula. Ini berarti bahwa orang-orang yang memiliki nisab zakat, wajib memberikan kadar tertentu dari hartanya kepada orang-orang miskin dan yang semisal dari mereka yang berhak menerima zakat." (Abdurrahman al-Jaziri, Al-Figh Ala al-Madzahib al-Arba'ah, 2003 : 536).

Menurut Yusuf al-Qardawi, yang mengemukakan pengertian zakat sebagai berikut: "Ditinjau dari segi bahasa, kata " zakat" merupakan kata (masdar) dari zaka yang berarti : "tumbuh dan berkembang." dan seseorang itu zaka berarti; orang itu baik. jadi arti zakat itu : berkah, tumbuh, bersih dan baik. Dari segi istilah 
berarti "sejumlah harta tertentu yang diwajibkan Allah diserahkan kepada orang-orang yang berhak" di samping berarti "mengeluarkan jumlah tertentu itu sendiri, jumlah yang dikeluarkan dari kekayaan itu disebut zakat, karena yang dikeluarkan menambah banyak, membuat lebih berarti dan melindungi kekayaan itu dari kebinasaan." (Yusuf al-Qardawi, 1973 : 137).

$$
\text { Wahbah al-Zuhayli }
$$

mengemukakan pengertian zakat dengan :

"Secara bahasa zakat berarti "tumbuh (numuww) dan bertambah (ziyadah). Jika diucapkan zaka al-zar' artinya tanaman itu tumbuh dan bertambah. Jika diucapkan zaka al-nafaqah, artinya; nafkah tumbuh dan bertambah jika diberkati. Kata ini juga sering dikemukakan untuk makna thaharah/suci . Pengertian "zakat" menurut syara' yang dikemukakan oleh Wahbah al-Zuhayli, ialah “ " يَجببُ فِى الْمَالِ wajib (dikeluarkan) dari harta, dengan mengemukakan pendapat para ulama imam mazhab. (Error! Hyperlink reference not valid. Juli 2018) Sementara ulama fikih yang lain memberikan pengertian Zakat dari segi istilah fikih berarti : "Sejumlah harta tertentu yang diwajibkan Allah diserahkan kepada orang-orang yang berhak," di samping berarti "mengeluarkan jumlah tertentu itu sendiri. Jumlah yang dikeluarkan dari kekayaan itu disebut zakat, karena yang dikeluarkan itu menambah banyak, membuat lebih berarti dan melindungi kekayaan itu dari kebinasaan". (Imam Nawawi, alMajmu'jilid 4: 324).

Di samping pengertian zakat di atas yang lebih ditekankan pada zakat harta atau zakat maal, dalam Islam di kenal juga adanya "Zakat Fitrah" yaitu kewajiban bagi seorang muslim yang memiliki kelebihan makanan pokok untuk menunaikannya pada hari raya Idul Fitri sebelum kutbah dibacakan atau pada hari-hari/ malam-malam akhir bulan suci Ramadhan sebanyak 1 Sha' $=4$ mud, 1 mud $=675$ gram atau $2.7 \mathrm{~kg}$, sama dengan 3,5 liter dari makanan pokok yang dikonsumsi dalam suatu daerah. Zakat ini diwajibkan bagi seluruh kaum muslimin meliputi orang dewasa, anak-anak dan hamba sahaya yang ada dalam tanggungan. Sebagaimana yang disebutkan dalam Hadis Rasulullah saw. dari Ibnu Umar r.a., ia berkata :

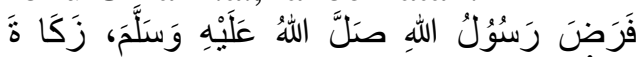

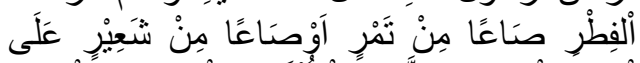

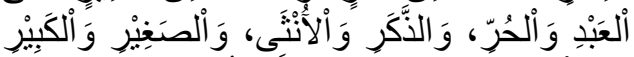

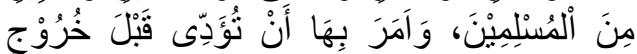

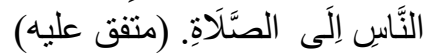

Artinya :

Rasulullah saw. mewajibkan zakat fitrah berupa satu sha,l kurma atau gandum pada budak, orang merdeka, lakilaki, perempuan, anak kecil dan orang dewasa dari umat Islam dan memerintahkan untuk membayarnya sebelum mereka keluar untuk shalat hari raya 'Id. (Hadis Muttafaq Alaihi). (Sahih Muslim : 462, Lihat juga Al-Hafidz Ibnu 
Hajar al-Asqalani, Bulugul

Maram, t.th. : 269)

Secara umum, satu sha' sama nilainya dengan $2,7 \mathrm{~kg}$ (3,5 liter) makanan pokok yang berlaku di masing-masing wilayah. Lihat $B u k u$ Saku Menghitung Zakat, (Direktorat Pemberdayaan Zakat, Kementerian Agama RI, 2013 : 8).

Dari pengertian-pengertian yang dikemukakan dapat disimpulkan bahwa zakat terdiri atas dua macam yaitu :

1. Zakat Harta atau Zakat Maal, yang merupakan bagian dari harta seseorang yang telah cukup nisab (kadarnya) dan haulnya. (waktunya satu tahun).

2. Zakat Fitrah adalah zakat yang wajib dibayarkan oleh setiap Muslim dalam bulan suci Ramadhan sampai dengan batas waktu sebelum dibacakan khotbah Idul Fitri, bahkan ada yang berpendapat zakat fitrah batasnya pada hari akhir Ramadhan yang diambil dari makanan pokok sehari-hari. Apabila zakat ini dibayarkan sesudah pelaksanaan Idul Fitri maka tidak lagi dinilai sebagai zakat, melainkan hanya sebagai sedekah sunat.

Dalam Islam, di samping kata zakat dikenal juga kata yang sinonim dengannya yaitu sedekah dan infaq, seperti disebutkan pada ayat dalam QS al-Taubah/9:60, kata sedekah diartikan sebagai zakat. Allah berfirman :

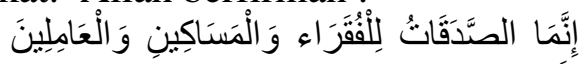

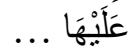

Terjemahnya :

Sesungguhnya zakat-zakat itu, hanyalah untuk orang-orang fakir, orang-orang miskin, Amil zakat... (www. dakwatuna.com 3 Juli 2018)
Demikian juga kata infaq disebutkan dalam QS. Ali Imran/ 3: 92

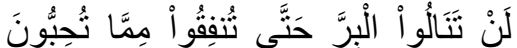

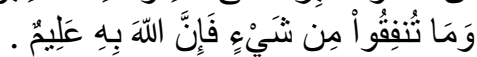

Terjemahnya :

Kamu sekali-kali tidak sampai kepada kebajikan (yang sempurna), sebelum kamu menafkahkan sebahagian harta yang kamu cintai. dan apa saja yang kamu nafkahkan, maka sesungguhnya Allah mengetahuinya. (www. saifuddinasm.com/1Juli2018)

Kedua ayat tersebut menunjukkan pada pengertian sedekah wajib atau zakat. yaitu ayat pertama disebutkan dengan "sedekah" dan ayat kedua disebutkan dengan "infaq". Sungguhpun demikian dalam pengertian sehari-hari yang hidup di lingkungan umat Islam, yang bersumber dari hukum fikih, terdapat definisi yang membedakan tiga istilah tersebut, sebagai berikut:

"Zakat" adalah sedekah yang sifatnya wajib berdasarkan ketentuan nisab dan haul, yang diberikan kepada mereka yang berhak menerimanya, yakni 8 (delapan) asnaf (kelompok) seperti yang tercantum dalam QS. al-Taubah 19:60. "Sedekah" adalah pemberian yang sifatnya sukarela tanpa ada ketentuan nisab, haul dan asnaf, walaupun pada umumnya sasarannya berpedoman pada ayat 60 surah at-Taubah. Adapun "infak" yaitu sesuatu yang dikeluarkan di luar zakat dan sedekah atau sebagai tambahan dari zakat, yang sifatnya juga sukarela dan pada umumnya dalam jumlah yang besar. (Yusuf Qardhawi, 
Fiqh al-Zakat, 1973 : 67. Lihat! juga Departemen Agama RI. Pembinaan Keluarga Sakinah, 2002: 366).

Dalam Undang-undang Nomor 23 Tahun 2011, tentang Pengelolaan zakat, ketiga kata tersebut juga dijelaskan sebagai berikut: zakat adalah harta yang wajib dikeluarkan oleh seorang muslim atau badan untuk diberikan kepada yang berhak menerimanya sesuai dengan syariat Islam. Infak adalah harta yang dikeluarkan oleh seseorang atau badan usaha di luar zakat untuk kemaslahatan umum. Sedekah adalah harta atau non harta yang dikeluarkan oleh seseorang atau badan usaha di luar zakat untuk kemaslahatan umum. (BAZNAS, Kompilasi Peraturan Perundang-undangan Pengelolaan Zakat, 2016 : 2)

Dari pengertian-pengertian zakat yang dikemukakan dapat dipahami bahwa zakat adalah suatu perintah agama yang wajib dilaksanakan/ditunaikan oleh orangorang Islam yang telah memenuhi syarat-syarat yang ditentukan dalam Islam. Apabila potensi ini dikembangkan dengan baik, dikelola dengan manajemen yang baik, transparan dan akuntabel/bertanggung jawab, dan didukung oleh peraturan perundang-undangan yang kuat, maka zakat akan menjadi suatu kekuatan raksasa dalam bidang ekonomi umat Islam. Hanya saja kekuatan ini belum terbangun dan ter aplikasi dengan baik.

Penelitian dalam penulisan ini menggunakan metode kualitatif. Menurut Sugiyono Penelitian kualitatif sering disebut metode penelitian naturalistik, karena penelitiannya dilakukan pada kondisi yang alamiah (natural setting) yaitu suatu keadaan yang apa adanya, tidak dimanipulasi oleh peneliti, sehingga kondisi pada saat peneliti memasuki obyek, setelah berada di obyek dan setelah keluar dari obyek relatif tidak berubah atau disebut juga sebagai metode etnografhi, karena pada awalnya metode ini lebih banyak digunakan untuk penelitian bidang antropologi budaya, karena data yang terkumpul dan analisisnya lebih bersifat kualitatif. ( Sugiyono, Memahami Penelitian Kualitatif, 2012: 1)

Lebih jauh dijelaskan, bahwa metode penelitian kualitatif adalah suatu metode yang digunakan untuk meneliti pada kondisi obyek yang alamiah, di mana peneliti adalah sebagai instrumen kunci, teknik pengumpulan data dilakukan secara trianggulasi (gabungan), analisis data bersifat induktif dan hasil penelitian lebih menekankan pada makna dari pada generalisasi. (Sugiyono, 2012 :2)

Menurut Lexy J. Moleong, penelitian kualitatif yaitu penelitian yang bermaksud untuk memahami fenomena tentang apa yang dialami oleh subjek penelitian.

$$
\text { Penelitian kualitatif }
$$

diistilahkan juga dengan inquiry naturalistic atau inkuiri alamiah. Pemakaian istilah ini dimaksudkan untuk lebih menekankan pada kealamiahan sumber data, atau dengan ungkapan lain adalah suatu metode yang meneliti kondisi objek 
secara alamiah (natural). (Lexy J. Moleong, Metode Penelitian Kualitatif, Cet.III, 1991: 5). Sementara Mc.Milan dan Schumacher dalam Nana Syaodih Sukmadinata mengata-kan bahwa secara umum penelitian kualitatif mempunyai dua tujuan, yaitu: 1) Menggambarkan dan mengungkap (to describe dan explore) dan 2) menggambarkan dan menjelaskan (to describe dan explain). (Nana Syaodih Sukmadinata, Metode Penelitian Pendidikan, Cet. IV, 2008 :96).

Penggunaan metode kualitatif dalam penelitian ini didasarkan kepada beberapa pertimbangan, pertama; menyesuaikan metode kualitatif lebih mudah apabila berhadapan dengan kenyataan ganda, kedua; dapat menyajikan secara langsung hakikat hubungan antara peneliti dengan responden, ketiga metode ini lebih peka dan lebih menyesuaikan diri dengan banyak penajaman pengarah bersama dan terhadap pola-pola nilai yang dihadapi. (Lexy J. Moleong, 1991 : 3)

Dalam penelitian ini akan dikaji secara mendalam terhadap implementasi Undang-Undang Nomor 23 Tahun 2011, Tentang Pengelolaan Zakat, dan Peraturan Pemerintah Nomor 14 Tahun 2014 Tentang Pelaksanaan Undangundang Nomor 23 Tahun 2011, sehingga dapat meningkatkan kualitas pengelolaan zakat di wilayah kota Palopo untuk mewujudkan kesejahteraan masyarakat, terutama bagi umat Islam yang masih berada di bawah garis kemiskinan.
Pemilihan Kota Palopo sebagai lokasi penelitian didasarkan pada beberapa pertimbangan sebagai berikut :

1). Bahwa berdasarkan observasi awal, Pengelolaan zakat di Kota Palopo belum sepenuhnya berjalan sesuai yang diharapkan, sehingga diperlukan langkah-langkah yang efektif untuk mencari solusi dalam mengatasi kendala-kendala yang ada.

2). Penelitian tentang Implementasi dari Undang-Undang Nomor 23 Tahun 2011 yang diberlakukan sejak ditetapkannya Peraturan Pemerintah Nomor 14 Tahun 2014 tentang Pelaksanaan Undangundang Nomor 23 Tahun 2011, khususnya dalam hal organisasi dan manajemen yang belum terlaksana sebagaimana dimaksud dari peraturan perundangundangan tersebut.

3). Berdasarkan hasil pengamatan dan informasi yang didapatkan bahwa pengelolaan zakat di Kota Palopo belum dapat berkembang sebagai suatu pranata keagamaan yang mampu memberikan solusi untuk kesejahteraan masyarakat terutama bagi yang masih berada di bawah garis kemiskinan.

\section{PEMBAHASAN}

Kota Palopo dikenal sebagai kota yang memiliki latar belakang sejarah masuknya Islam di Sulawesi Selatan, karena di kota ini terdapat sebuah monumen sejarah, yaitu salah satu mesjid tertua di Sulawesi Selatan yang dibangun pada tahun 1604 M, atas perintah Raja Luwu saat itu "Datu Lapatiware Daeng Parabung".(Sanusi Dg. Mattata, Luwu Dalam Revolusi, 1968: 57), 
Sekarang mesjid tersebut masih berdiri kokoh dalam bentuknya yang asli dikenal dengan nama Mesjid Jami' Tua Palopo, yang letaknya berdekatan dengan istana Raja Luwu di Kota Palopo.

Kota ini juga pernah menjadi ibu kota kerajaan Luwu, salah satu kerajaan tertua di Sulawesi Selatan yang memiliki pengaruh yang begitu luas sampai ke daerah Sulawesi Tenggara, dan Sulawesi Tengah pada saat itu.

Kota ini memiliki sumber daya alam yang sangat potensial untuk dikembangkan, termasuk dalam hal ini adalah potensi zakat yang apabila dikelola dengan baik dalam pengumpulan, pendistribusian dan pendayagunaannya akan menghasilkan suatu kekuatan yang besar untuk mengentaskan masyarakat dari kemiskinan. Hasil penelitian memberikan gambaran bahwa potensi zakat di kota Palopo dapat mencapai nilai sebesar Rp. 20.000.000.000,- (baca: Dua puluh milyar Rupiah) setiap tahun.

Potensi zakat yang ada di Kota Palopo jika dihitung dari berbagai jenis/komponen harta yang dapat dizakati berdasarkan data dan informasi yang diperoleh dari berbagai instansi pemerintah di kota Palopo, kemudian dikonversi dengan nilai rupiah, maka dapat dilihat perkiraan nilai zakat yang dapat dikumpulkan dalam satu tahun sebagaimana dalam tabel berikut:
Tabel 1. Perkiraan Potensi Zakat di Kota Palopo

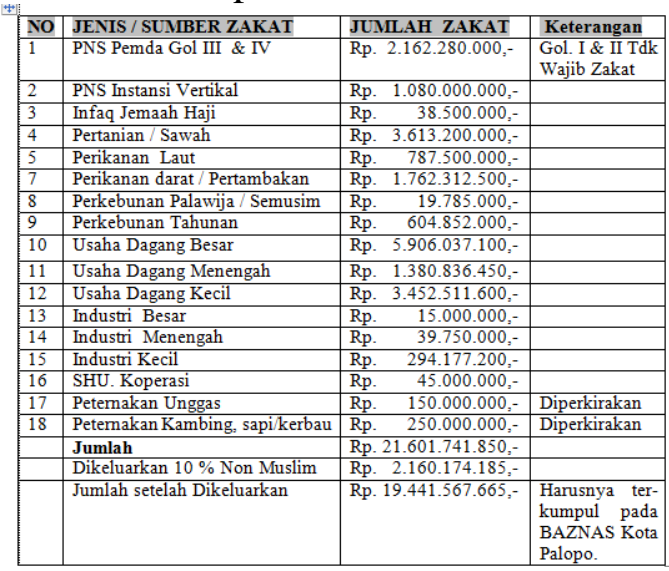

Sumber Data: Kantor Bappeda, Kota Palopo, 2016.

Data tersebut adalah data perkiraan potensi zakat yang kemungkinan besar dapat diwujudkan jika zakat di Kota Palopo dilaksanakan pengelolaannya dengan baik, transparan dan bertanggungjawab. Namun demikian jika dibandingkan dengan hasil perolehan zakat oleh BAZNAS Kota Palopo, sebagai lembaga resmi yang mengelola zakat, dapat dikatakan masih terjadi deviasi yang begitu jauh antara harapan (potensi zakat yang ada) dengan kenyataan dari hasil perolehan zakat setiap tahun. Berikut ini dapat dilihat hasil pengumpulan zakat oleh BAZNAS Kota Palopo berdasarkan laporan tahun 2015-2016 sebagai berikut:

Tabel 2. Hasil Pengumpulan Zakat di Kota Palopo tahun 2015-2016

\begin{tabular}{|c|l|l|l|}
\hline NO & JENIS ZAKAT & JUMLAH ZAKAT & KETERANGAN \\
\hline 1 & Zakat Fitrah & Rp. $1.387 .285 .335,00$ & $\begin{array}{l}\text { Disalurkan langsung di } \\
\text { mesjid-mesjid }\end{array}$ \\
\hline 2 & Zakat Maal/Harta & Rp. $73.005 .000,00$ & \\
\hline 3 & Zakat Profesi/Gaji & Rp. $240.490 .030,00$ & \\
\hline 4. & Infaq/Sedekah Profesi & Rp. $133.650 .660,00$ & \\
\hline 5. & $\begin{array}{l}\text { Infaq Rumah Tangga } \\
\text { Muslim (RTM) }\end{array}$ & Rp. $168.938 .000,00$ & \\
\hline 6 & Infaq Jemaah Haji & Rp. $38.500 .000,00$ & \\
\hline & J u m la h & Rp. 2.041.869.025,00 & \\
\hline \multicolumn{2}{l|l}{ Sumber: Kantor BAZNAS Kota Palopo 2016. } \\
\hline
\end{tabular}


Data ini memberikan informasi tentang kondisi pengumpulan zakat di Kota Palopo yang sekaligus dapat dipahami bahwa dalam pengumpulan zakat yang dilakukan oleh BAZNAS Kota Palopo masih sangat jauh dari jumlah perkiraan potensi zakat yang ada.

Adapun hasil pendistribusian zakat yang dilakukan oleh BAZNAS Kota Palopo berdasarkan laporan Tahun 2016 dengan berbagai komponen penerima zakat, lihat tabel berikut:

Tabel 3. Daftar Alokasi Pendistribusian Dana Zakat di Kota Palopo.

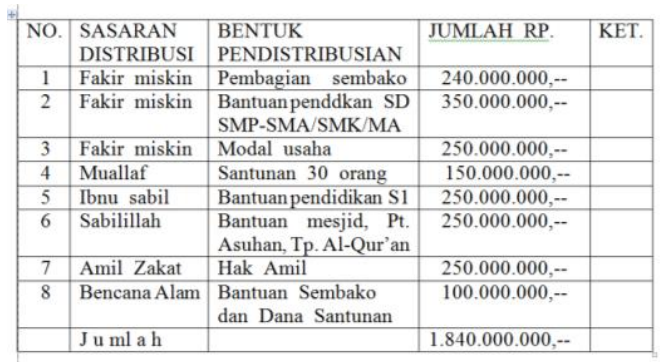

Sumber: Kantor BAZNAS Kota Palopo. 2016.

Dari informasi yang diperoleh tentang pengelolaan zakat di Kota Palopo, dari lembaga pengelola zakat yang ada yaitu BAZNAS Kota Palopo, dapat dipahami bahwa pengelolaan zakat di Kota Palopo belum berjalan sebagaimana yang diharapkan, baik dari aspek hukumnya yaitu implementasi Undang-undang Nomor 23 Tahun 2011 tentang Pengelolaan Zakat, (dalam hal kepengurusan organisasi ) maupun dalam pengembangan aspek sosial dan ekonominya.

Dalam tulisan ini berusaha memberikan gambaran tentang langkah-langkah yang dapat dilakukan agar pengelolaan zakat dapat memberikan kontribusi yang besar dalam rangka pengentasan kemiskinan dan peningkatan kualitas hidup umat Islam di kota Palopo sebagai berikut:

1. Dalam aspek Yuridis (hukum) beberapa langkah yang harus dilakukan :

a. Penataan Kelembagaan BAZNAS di Kota Palopo

Dari penelitian yang dilakukan di Kota Palopo, pada berbagai instansi pemerintah dan Kantor BAZNAS Kota Palopo, menunjukkan bahwa pengelolaan zakat di Kota Palopo saat ini sudah berjalan, hanya saja belum maksimal dalam pelaksanaannya. Berbagai hal yang menyebabkan di antaranya adalah kepengurusan BAZNAS Kota Palopo belum menyesuaikan dengan peraturan perundang-undangan yang berlaku. Hal ini perlu segera dilakukan mulai dari sistem rekrutmen pengurus, penataan struktur organisasi/kelembagaan, mekanisme kerja, pelaporan, dan evaluasi kinerja organisasi sudah harus disesuaikan dengan Undang-undang Nomor 23 Tahun 2011 Tentang Pengelolaan Zakat dan Peraturan Pemerintah Nomor 14 Tahun 2014, tentang Pedoman Pelaksanaan UU Nomor 23 12011.

b. Peningkatan kesadaran masyarakat Islam untuk berzakat melalui organisasi Pengelola Zakat yang resmi, dengan kegiatan sosialisasi dan edukasi kepada masyarakat Islam untuk pembentukan Unit Pengumpul Zakat (UPZ) pada Instansi Pemerintah, Badan Usaha Milik Daerah, dan Mesjid-mesjid sesuai tingkatan 
kewenangan berdasarkan UU Nomor 23 Tahun 2011 dan PP. Nomor 14 tahun 2014.

c. Peningkatan Kualitas SDM pengurus BAZNAS agar mampu menggunakan perangkat teknologi informasi seperti wifi, program System Informasi Zakat Terpadu (SIMZAT) dan Sistem Informasi Manajemen Baznas (SIMBAZ) sehingga Informasi perzakatan dapat diakses secara online oleh masyarakat, dan pengadaan sarana/prasarana yang menunjang proses pengelolaan zakat, baik dalam pengumpulan, pendistribusian maupun dalam hal pendayagunaan zakat.

2. Dalam aspek pengembangan sosial dan ekonomi melalui langkah-langkah :

a. Peningkatan Pengumpulan Zakat oleh Pengurus BAZNAS bekerja sama dengan Instansi Pemerintah Kota Palopo, dan Pemerintah Kecamatan, Badan Usaha Milik Daerah, Pengurus Mesjid, Sekolah dan lembaga-lembaga sosial lainnya yang ada.

b. Peningkatan kualitas pendistribusian zakat bekerja sama dengan UPZ Kabupaten, UPZ Kecamatan dan UPZ. Tingkat Desa/Kelurahan, serta pengurus mesjid dan lembagalembaga sosial lainnya

c. Peningkatan kualitas pendayagunaan zakat untuk kegiatan bantuan peningkatan kualitas SDM kaum dhuafa (fakir-miskin) bekerja sama dengan Perguruan Tinggi setempat, sekolah-sekolah Tingkat SMA/SMK/MA dan Lembaga-lembaga Kursus ketrampilan serta Balai

Latihan Kerja (BLK) yang ada. Mudah-mudahan tulisan ini dapat menjadi salah satu referensi/tambahan informasi dalam pengelolaan zakat di kota Palopo, bahkan secara nasional, agar pengelolaan zakat di Indonesia dapat memberikan suatu dorongan bagi umat Islam untuk menjadikan zakat sebagai gaya hidup (life style). Yaitu Para muzakki baru merasa nikmat dan bahagia hidupnya jika mereka telah menunaikan kewajiban berzakat. Dengan satu semboyan dalam pengelolaan zakat yaitu: "Dengan zakat kita wujudkan masyarakat yang sejahtera lahir batin, maju dan mandiri dalam Negara Kesatuan Republik Indonesia menuju Baldatun Tayyibah Warabbun Gafur".

\section{PENUTUP}

1. Dalam Pengelolaan zakat di Kota Palopo penerapan aspek yuridis/hukum sudah harus dilakukan, dengan menyesuaikan lembaga/ organisasi Pengelola zakat (BAZNAS) Kota Palopo dengan seluruh peraturan perundang-undangan yang berlaku dalam negara Republik Indonesia, baik dalam pengembangan organisasi, manajemen pengelolaan, sistem pelaporan dan evaluasi kinerja organisasi agar dalam pelaksanaannya, dapat menumbuhkan kesadaran umat Islam (para muzakki) untuk berzakat melalui BAZNAS Kota Palopo. Sehingga BAZNAS menjadi lembaga 
Pengelolaan Zakat yang berkembang, maju dan mandiri.

2. Pengurus BAZNAS Kota Palopo dalam mengelola zakat yang dikumpulkan dari umat Islam, harus berupaya menerapkan aspek yuridis/ hukum (peraturan perundangundangan yang berlaku dan fikih/hukum Islam), serta mengembangkan aspek sosial dan ekonomi dalam pengelolaan zakat untuk pemberdayaan masyarakat kaum dhuafa, dengan berusaha meningkatkan kualitas pengumpulan, pendistribusian dan pendayagunaan zakat yang sesuai dengan Undang-undang Nomor 23 Tahun 2011 tentang Pengelolaan Zakat dan peraturan perundang-undangan lainnya yang berkaitan dengan pengelolaan zakat untuk menjadikan zakat lebih berdaya guna dan berhasil guna dalam mewujudkan kesejahteraan masyarakat dan meningkatkan kualitas hidup umat Islam.

\section{DAFTAR PUSTAKA}

al-Jaziri, Abdurrahman. 2003. AlFiqh 'Ala al-Madzahib alArba'ah Cet. I, Juz 3. Beirut, Libanon: Darul Qutub alIlmiyah.

Abu Zahra, Muhammad. 2004. Zakat Dalam Perspektif Sosial, Cet. III. Jakarta: Pustaka Firdaus.

Al-Asqalani, Al-Hafidz Ibnu Hajar. t.th. Bulugul Maram. Mesir: Al-Maktabah al-Tijariah alQubra.

Ali, Muhammad Daud. 1984. Kedudukan Hukum Islam
Dalam Sistem Hukum

Indonesia, Jakarta: Yayasan Risalah.

Badan Amil Zakat Nasional (BAZNAS), Kompilasi

Peraturan Perundang-

Undangan Pengelolaan Zakat, Jakarta : Badan Amil Zakat Nasional, 2016.

Departemen Agama RI. 2002. Pembinaan Keluarga Sakinah. Jakarta: Dirjen Bimas Islam dan Penyelenggaraan Haji.

J. Moleong, Lexy. 1991. Metode Penelitian Kualitatif, Cet.III. Bandung: Remaja Rosdakaya.

Kementerian Agama RI. 2015. AlQur'an dan Terjemah, Revisi Terjemah oleh Lajnah Pentashihan Mushaf AlQur'an. Jakarta : Dharma Art.

Qardawi, Yusuf. 1973. Fiqh alZakah, Cet. II. Beirut Lubnan: Muassasah al-Risalah, 1973.

Sugiyono. 2012. Memahami Penelitian Kualitatif. Bandung: Alfabeta.

Sukmadinata, Nana Syaodih. 2008. Metode Penelitian Pendidikan. Cet. IV; Bandung; Remaja Rosdakaya.

al-Zuhayli, Wahbah. 1985. Al-Figh al-Islami wa Adillatuh. Cet. ke II. Damsyik : Al-Maktabah alIlmiyah.

www.noerkhaliazelaikha.blogspot.co m/ 6 Agustus 2018

www.wardahcheche.blogspot.com/5 Juli 2018

www.saifuddinasm.com/1Juli2018 www. Dakwatun . com/19 September 2018 